Runnig Tittle: Syllidae-Protozoan epibiosis

Corresponding author: patricia.alvarez@uam.es

\title{
The tag-along friendship: epibiotic protozoans and syllid polychaetes. Implications for the taxonomy of Syllidae (Annelida), and description of three new species of Rhabdostyla and Cothurnia (Ciliophora, Peritrichia).
}

Álvarez-Campos, Patricia ${ }^{1 *}$, Gregorio Fernández-Leborans ${ }^{2}$, Aida Verdes ${ }^{3}$, Guillermo San Martín ${ }^{1}$, Daniel Martin ${ }^{4}, \&$ Ana Riesgo ${ }^{5}$

1 Departamento de Biología (Zoología), Universidad Autónoma de Madrid, Facultad de Ciencias, Cantoblanco 28049, Madrid, Spain.

2 Departamento de Zoología, Universidad Complutense de Madrid, Facultad de Biología, C/ José Antonio Novais, 12, 28040, Madrid, Spain

3 Department of Natural Sciences, City University of New York, Baruch College, 55 Lexington Avenue, New York 10010 NY, USA

4 Department d'Ecologia Marina, Centre d'Estudis Avançats de Blanes, CEAB-CSIC, c/ Accés a la cala St Francesc, 14, 17300, Blanes, Spain

5 Departamento de Biología Animal, Facultad de Biología, Universitat de Barcelona, Av. Diagonal 643, 08028, Barcelona, Spain.

\begin{abstract}
The presence of peritrich ciliate epibionts Rhabdostyla sp. and Cothurnia sp. on Syllidae polychaetes is reported here for the first time, including the description of three new species of epibiont ciliates. The protozoans were mainly found at intersegmental furrows, close to parapodial bases of newly collected specimens of Syllis magdalena, Syllis sp., Salvatoria sp. and Salvatoria concinna n. comb. from Chile, Syllis prolifera from Spain and Prosphaerosyllis magnoculata from New Zealand. In addition, epibiont protozoans were found on the dorsal surface, nuchal organs, mouth opening and anterior cirri of Syllis elongata from Peru, and the ventral surface of Typosyllis macropectinans from Australia. The discovery of protozoan epibionts on syllid polychaetes has important taxonomic implications that are discussed here. The presence of papillae that
\end{abstract}


are in fact misinterpreted ciliate epibionts has been considered a valid character to distinguish among species or to erect new species of Syllidae, and thus the real origin of papillae-like structures in polychaetes, should be carefully assessed.

Key words: Syllidae-protozoan epibiosis, symbiosis, peritrich ciliates, new species, taxonomy. 


\section{Introduction}

Polychaetes are known for their facility to establish a wide array of interconnections with other organisms, including different symbiotic associations (Martin \& Britayev, 1998). Symbiosis in a wider sense includes any association between two organisms living together with a gradient of positive or negative consequences for at least one of them (Henry, 1966; Boucher, James \& Keeler, 1982; Bush et al., 2001) which, in some cases, leads some or all partners to lose the ability to live as free-living organisms (Rhode, 1981). Such associations are named differently depending on the degree of "intimacy" and the consequences for the involved partners, and include mutualism, commensalism and parasitism, the latter two widely reported in polychaetes (Martin \& Britayev, 1998).

Additionally, depending on the location of the symbiont relative to the host, the association can be considered endobiotic, when the symbiont lives inside the host tissues, or epibiotic, when it lives on the external surface of the host. In particular, epibiosis is a spatially close association between two or more organisms, the epibiont that colonizes the surface of live substrates, and the basibiont that gives support to the former (Wahl, 1989; Fernández-Leborans \& Gabilondo, 2006). Interestingly, polychaetes have also been described as epibionts of a variety of sessile organisms, such as sponges (e.g., Pawlik, 1983; Lattig \& Martin, 2009, 2011a, b; Lattig, Martin \& Aguado, 2010; Álvarez-Campos, San Martín \& Aguado, 2012), corals (e.g., Glasby \& Watson, 2001; Martin et al., 2002 Glasby et al., 2012; Álvarez-Campos San Martín \& Aguado, 2013), bryozoans (e.g., Morgado \& Amaral, 1985), and cirripeds (Hernández, Muñoz \& Rozbaczylo, 2001). Even though the majority of studies dealing with polychaetes associations, including the aforementioned, describe relationships in which the polychaete is the symbiont, they also play an important role as hosts of other organisms, such as other polychaetes, copepods, loxosomatids, nematods, and also protozoans (e.g. Nielsen, 1964; Martin \& Britayev, 1998; Rangel et al., 2009; Wakeman \& Leander, 2013). In this study, we report for the first time the role of several species of syllid polychaetes as hosts of peritrichid ciliate protozoan epibionts.

Ciliate protozoans are commonly reported as internal parasites of numerous metazoans (Barel \& Kramers, 1977; Taboada et al., 2013) including polychaetes (Wakeman \& Leander, 2013 and references herein). In addition, ciliates living on the external surfaces of a wide variety of aquatic Metazoa are commonly observed, most of 
them belonging to the subclass Peritrichia (e.g., Corliss, 1961, 1979; Kahl, 1930-1935; Baldock, 1986; Smith, 1986; Weissman et al., 1993; Gilbert \& Schröder, 2003; RegaliSeleghim \& Godinho, 2004; Fernández-Leborans, 2010; Sedlacek et al., 2013). It is worth noting that, despite their ubiquitous presence as epibionts of aquatic metazoans, ciliate peritrich epibionts have only been reported in just a handful of polychaete species (Knox \& Hicks, 1973; Magnini \& Verni, 1988; Arias, Anadón \& Paxton, 2010).

We expand here the knowledge on polychaete epibionts, reporting for the first time the occurrence of epibiont ciliate protozoans of the subclass Peritrichia from two different genera (Rhabdostyla and Cothurnia) on eleven different species of polychaetes within the family Syllidae: newly collected specimens of Syllis magdalena WesenbergLund, 1962, Syllis sp.1, Syllis sp.2, Salvatoria concinna (Westheide, 1974) n. comb., Salvatoria sp., Syllis prolifera Krohn, 1852, Syllis elongata (Johnson, 1901), and museum specimens of Typosyllis microoculata (Hartmann-Schröder, 1965), Typosyllis macropectinans Hartmann-Schröder, 1982, Parapionosyllis papillosa (Pierantoni, 1903). Interestingly, we found two new species of epibionts of the genus Rhabdostyla, Rhabdostyla mapuche n. sp. and Rhabdostyla taboadai n. sp., and one new species of the genus Cothurnia, Cothurnia kiwi n. sp. (Table 1). Some species of Rhabdostyla have been previously reported as epibionts of other polychaete families, but noteworthy, the association between Cothurnia sp. and the phylum Annelida has never been observed before.

\section{Material and Methods}

Specimens of Syllis magdalena, Salvatoria concinna n. comb., Salvatoria sp. and Syllis spp. were collected in Central Chile (Las Cruces, Valparaíso Region; $33^{\circ} 30.06^{\prime}$ S, $71^{\circ} 37.55^{\prime} \mathrm{W}$ ) in January 2013, on intertidal algae including holdfasts of Lessonia spictata, and thalli of Corallina sp. and Gelidium sp. Syllis elongata specimens were collected in Peru (Albacora, Tumbes, Lima; $12^{\circ} 08.37^{\prime} \mathrm{S}, 7^{\circ} 01.36^{\prime} \mathrm{O}$ ), by SCUBA on unidentified sponges at $20 \mathrm{~m}$ depth, in March 2013. Specimens of Syllis prolifera were collected by snorkeling and SCUBA in the Mediterranean Sea (Punta Santa Anna, Blanes, Spain; $41^{\circ} 40.25^{\prime} \mathrm{N}, 02^{\circ} 48.06^{\prime} \mathrm{E}$ ), among an unidentified brown alga, in September 2013. Samples of Prosphaerosyllis magnoculata were collected by SCUBA diving in the East (Wellers Rock, Dunedin; 4550.52’S, 170³7.31’E, $5 \mathrm{~m}$ 
depth) and West (Tauranga Bay, Cape Foulwind; 4146.23’S-171'27.12’E, intertidal) coasts of New Zealand, on unidentified algae during February 2012. Typosyllis macropectinans, was loaned from the Australian Museum (AM), originally collected in East Australia (North of Batemans Bay, New South Wales; 3643.59’S, 14959.16’E), in 2004. The samples of the species originally described as Typollis microoculata were loaned by the Hamburg Zoological Museum (HZM), originally collected in Hawaii (Maui; 2045.09’ N, 156²9.26’W). Type material of Parapionosyllis papillosa was not available, but original description and drawings from Pierantoni (1903) and (Fauvel, 1923) as well as specimens identified and described by Campoy (1982) were examined at the Museum of the Universidad de Navarra.

The newly collected samples were sorted using an Olympus SZ61 stereoscope, and fixed in either $10 \%$ formalin buffered in seawater, $96 \%$ ethanol or $2.5 \%$ glutaraldehyde solution. Syllids from Chile were studied under an Olympus CX21 microscope with an attached Micro-imaging digital camera at Estación Costera de Investigaciones Marinas de Las Cruces (ECIM). The rest of the specimens were studied under a Nikon Optiphot microscope with a differential interference contrast system (Nomarsky) at Universidad Autónoma de Madrid and a Zeiss Axioplan II compound microscope connected to a ProgRes C10 Plus digital camera (Jenoptics, Jena) at CEAB. For scanning electron microscopy (SEM), the specimens were critically point dried with an Emitech K850 Critical Point Dryer, gold-coated with a Q150T-S Turbo-Pumper Sputter Coater, and examined with a Hitachi S-3000N electron microscope at the Servicio Interdepartamental de Investigación (SIDI) of the Universidad Autónoma de Madrid (UAM) and a HITACHI HIGH-TECH TM3000 Tabletop at CEAB. For transmission electron microscopy (TEM), specimens fixed in 2.5\% glutaraldehyde solution in $0.4 \mathrm{M}$ PBS with $\mathrm{NaCl}$ were postfixed in osmium tetroxide $1 \%$ in PBS, dehydrated in an ascending acetone series, and further embedded in epoxy resin and viewed in a JEOL 1010 microscope at the Serveis Científico-Técnics at Universitat de Barcelona (UB). Protozoan epibionts were identified following Fernández-Leborans \& Castro de Zaldumbide (1986); they were isolated and treated using the silver carbonate staining technique and also methyl green and neutral red staining. Light microscope images and morphometric data of the epibionts were obtained using Image Analysis (KS300 Zeiss). All newly collected specimens were deposited at the Museo Nacional de Ciencias Naturales de Madrid (MNCN). 


\section{Results}

This is the first formal report of peritrich ciliate protozoans living as epibionts of syllid polychaetes. Numerous epibiont populations of Rhabdostyla spp. and Cothurnia sp. were observed living on newly collected and museum specimens of eleven different species of the family Syllidae. Interestingly, among the ciliate epibionts, two new species of Rhabdostyla and one new species of Cothurnia have been identified and described here (see taxonomy section below); Rhabdostyla mapuche n. sp. was observed on S. magdalena, Syllis sp.1, Syllis sp.2, Salvatoria concinna n. comb. and Salvatoria sp. from Chile. Rhabdostyla taboadai n. sp. was discovered on S. prolifera from the Spanish Mediterranean coast and Cothurnia kiwi was identified on $P$. magnoculata specimens from New Zealand (Figs. 1-5). Additionally, unidentified Rhabdostyla spp. epibionts were observed on S. elongata from Peru and T. macropectinans from Italy (Fig. 6). Two Syllidae museum specimens originally described as T. microoculata and P. papillosa, also presented ciliate epibionts of the genus Rhabdostyla that were misunderstood as papillae (Fig. 7). This overlooked epibiosis of ciliates on syllids might have important taxonomic implications, since the papillae have been considered as a valid character to distinguish among species or to erect new species. Indeed, Typosyllis microoculata is a synonymy of S. prolifera (see taxonomy section below).

It is also worth noting that this symbiotic relationship between protozoans and syllids is not restricted to a single geographical area, since the specimens presenting peritrichid ciliates described here have been observed in the Pacific Ocean (Chile, New Zealand, Australia, Hawaii) and Western Mediterranean Sea (Spain and Italy) (Table 1).

\section{Association of syllids and ciliates}

The epibiotic relationship between ciliates and polychaetes occurred in 22 specimens collected from holdfasts and thalli of several algae (Table 1). In every syllid specimen, ciliates were present in most segments at intersegmental furrows, close to parapodial bases, including the museum specimens originally described as $T$. microoculata and P. papillosa (Figs. 1-7). In addition, Syllis magdalena and Syllis sp. 2 presented ciliates on the prostomium and S. elongata around the nuchal organs, mouth 
opening, and anterior cirri (Fig. 3G, 6A-B). In most cases, only one ciliate was found on the base of the parapodia in all specimens (Fig. 1, 3A-F, 4A, G, 5A-C, 6A-C). However, two or three ciliates may share the same parapodia, as observed in Syllis sp. 2 (Fig. 3H, 4C, 5D). Only in T. macropectinans most of the posterior ventral part was covered by a large number of ciliates (Fig. 6 D-F).

\section{Taxonomic account of ciliate protozoans}

Phylum Ciliophora Doflein, 1901

Subphylum Intramacronucleata Lynn, 1996

Class Oligohymenophorea De Puytorac et al., 1974

Subclass Peritrichia Stein, 1859

Order Sessilida Kahl, 1933

Family Vaginicolidae de Fromentel, 1874

Genus Cothurnia Ehrenberg, 1831

Diagnosis. Loricate peritrichs with one or two zooids per lorica. Lorica attached aborally by stalk. Lorica without valves or operculum. Inner part of lorica may present internal lining or septum that can contain a mesostyle. Zooid may attach to lorica directly or via an endostyle (Warren \& Paynter, 1991; Lynn \& Small, 2000).

Ecology. Usually found as epibionts in many crustacean groups, including copepods, decapods, amphipods, isopods, and ostracods. Two species have been also found on tanaids (Fernández-Leborans \& Sorbe, 2003). This is the first report of the genus living in epibiotic association with the phylum Annelida.

Cothurnia kiwi n. sp. Álvarez-Campos, Fernández-Leborans \& San Martín Figure 1, 2A

Material examined. New Zealand: Holotype (MNCN 39.01/5), 3 paratypes (one mounted for SEM) (MNCN 39.02/6-8), Tauranga Bay, Cape Foulwind, 4146.23’S$171^{\circ} 27.12^{\prime}$ E, unidentified coralline alga, intertidal, February $9^{\text {th }}$, 2012; Two paratypes (MNCN 39.02/9-10), Wellers Rock, Dunedin, 4550.52’S, 170³7.31’E, unidentified 
red alga, $5 \mathrm{~m}$ depth, February $7^{\text {th }}$, 2012. One paratype (MNCN 39.02/11), Akaroa Bay, $43^{\circ} 48.50^{\prime}$ S- $172^{\circ} 57.15^{\prime}$ E, unidentified coralline alga, intertidal, February $5^{\text {th }}, 2012$.

Comparative material. See Table 2 for comparisons.

Description. Elongated pseudocylindrical lorica of 40.87-53.14 $\mu \mathrm{m}$ long and 16.81$19.2 \mu \mathrm{m}$ wide; lorica shows transverse furrows and ridges from opening to rear end, with grooves more pronounced in middle area; opening of the lorica $(10.5-13.7 \mu \mathrm{m})$ shorter than maximum body width with edges curved outward. Ciliate body 26.98$36.05 \mu \mathrm{m}$ long, and 14.72-16.64 $\mu \mathrm{m}$ wide, connected to external stalk by a mesostyle; mesostyle presents longitudinal striation. External stalk 11.1-22.5 $\mu \mathrm{m}$ long and 2.5$2.08 \mu \mathrm{m}$ wide. Oval macronucleus (7.36-11.09 $\mu \mathrm{m}$ long; 8.58-10.4 $\mu \mathrm{m}$ wide) located in anterior half of the body. Spherical micronucleus located near the macronucleus.

Remarks. Cothurnia kiwi n. sp. is characterized by having a mesostyle but lacking an endostyle, and by having an oval anterior macronucleus. Cothurnia kiwi n. sp. is compared to the most similar species of the genus in Table 2. Cothurnia curvula and $C$. mobiusi lack mesostyle and endostyle, and have a wider lorica than C. kiwi n. sp. Cothurnia cyclopis and Cothurnia cytheridae differ from C. kiwi n. sp. in having mesostyle and endostyle; the latter also presents a larger smooth lorica. Cothurnia membranoloricata has a shorter external stalk than C. kiwi.

Ecology. Attached to the base of parapodia in specimens of Prosphaerosyllis magnoculata.

Distribution. New Zealand

Etymology. The name refers to "kiwi”, a common term used for New Zealand people.

Family Epistylididae Kahl, 1933

Genus Rhabdostyla Kent, 1881

Diagnosis. Solitary peritrich ciliates with short non-contractile stalks, mostly inverted bell-shaped bodies and peristome with well-defined lip (Kent, 1880-81; Kahl, 1930-35; Lynn \& Small, 2000). Taxonomical characters for identification of currently known species are summarized in Table 2.

Ecology. Mostly epibionts of freshwater invertebrates, particularly crustaceans, insects and oligochaetes (Kahl, 1935; Precht, 1935; Nenninger, 1948; Fernandez-Leborans \& Tato-Porto, 2000; Regali-Seleghim \& Godinho, 2004). Some species also reported in 
marine ecosystems, in association with different invertebrates, including polychaetes (Table 2). This is the first report of the genus in association with Syllidae.

Rhabdostyla mapuche n. sp. Álvarez-Campos, Fernández-Leborans \& Verdes Figures 2B, 3, 4A-E

Material examined. Chile, Valparaíso Region, Las Cruces, 33³0.06’S-71³7.55’W: Holotype (MNCN 39.02/12) and 7 paratypes (one mounted for SEM and one fixed for TEM) (MNCN 39.02/13-19), holdfast of Lessonia spicata, intertidal, February $14^{\text {th }}$, 2012; one paratype (MNCN 39.02/20), thallus of Gelidium sp., intertidal, February $14^{\text {th }}$, 2012; 4 paratypes (MNCN 39.02/21-24), thalli of Corallina sp. and Gelidium sp., intertidal, February $14^{\text {th }}$.

Comparative material. See Table 3 for comparisons.

Description. Body shape globular to spherical, 23-31 $\mu \mathrm{m}$ long, 16-19 $\mu \mathrm{m}$ wide; when contracting, posterior and anterior folds cover contracted part, appearing oval with a deep indentation that contains part of contracted posterior end. Peristomial (oral) disk 20-23 $\mu \mathrm{m}$ long, with 9-14 ciliary bands. Macronucleus c-shaped, anterior, near cell periphery. Cortex distinctly transverse-striated, with 36-39 silverlines. Micronucleus round, close to macronucleus. Stalk short, thick, 3-6 $\mu$ m long, 4-6 $\mu \mathrm{m}$ wide, with longitudinal sinuation. Basal disk absent.

Remarks. Rhabdostyla mapuche n. sp. is unique among the genus because of its small size. It differs from $R$. taboadai n. sp. in its shorter stalk and lack of basal disk. Unlike $R$. taboadai n. sp., $R$. variabilis, $R$. nereicola and $R$. arenaria, $R$. mapuche $n$. sp. has a cshaped macronucleus similar to R. commensalis but longitudinally located. Rhabdostyla scyphoides is similar in body shape but larger and not striated and also differs from $R$. libera in body shape and striation.

Ecology. Attached to intersegmental furrows, close to parapodial bases of Syllis magdalena, Syllis sp. 1 and Syllis sp. 2., Salvatoria concinna n. comb., and Salvatoria sp. Also attached to prostomium of Syllis magdalena and Syllis sp. 2.

Distribution. Central Chile.

Etymology. The name refers to the Mapuche, a group of indigenous inhabitants of south-central Chile and south-western Argentina.

Rhabdostyla taboadai n. sp. Álvarez-Campos, Fernández-Leborans, Riesgo \& Martin 
Figures 4E, 5

Material examined. Mediterranean Sea: holotype (MNCN 39.02/25) and 2 paratypes (one mounted for SEM) (MNCN 39.02/26-27), Punta Santa Anna, Blanes, Spain, 41 ${ }^{\circ} 40.25^{\prime}$ N, 0248.06’ E, unidentified brown alga, 3 m depth, September $23^{\text {rd }}$, 2013.

Comparative material. See Table 3 for comparisons.

Description. Body shape globular, elongated, 30-45 $\mu \mathrm{m}$ long, 15-23 $\mu \mathrm{m}$ wide, anterior end rounded to slightly projecting; when contracting, posterior and anterior folds cover the contracted part, appearing oval, with deep indentation containing part of contracted posterior end. Peristomial (oral) disk 26-29 $\mu \mathrm{m}$ long, with 11-18 ciliary bands. Macronucleus multilobed, usually anterior, near cell periphery. Micronucleus absent. Cortex distinctly transverse-striated, with 38-42 silverlines. Stalk 14-17 $\mu \mathrm{m}$ long, 7-9 $\mu \mathrm{m}$ wide, with longitudinal sinuation. Basal disk 8-12 $\mu \mathrm{m}$ in diameter.

Remarks. Rhabdostyla taboadai n. sp. is unique because of its oval and elongated body shape and its multilobular macronucleus. The rest of distinctive characters are discussed in R. mapuche remarks.

Ecology. Attached to intersegmental furrows, close to parapodial bases of Syllis prolifera.

Distribution. Costa Brava (Spanish North-Eastern Mediterranean coast).

Etymology. Named after Dr. Sergi Taboada, polychaetologist, colleague and friend, for his help collecting and sorting the Mediterranean material and for his useful advice and support.

\section{Taxonomic account of syllids}

Salvatoria concinna n. comb. (Westheide, 1974)

Brania concinna Westheide, 1974, 44: 91, fig. 41

San Martín (2005) rescued Salvatoria McIntosh, 1885 for some species previously described as Brania Quatrefages, 1866. The genus formerly included Brania concinna Westheide, 1974 from Galápagos Islands, but the species is transferred here to the genus Salvatoria because it broods dorsally. This is also the first report of Salvatoria concinna (Westheide, 1974) n. comb. for Chilean waters.

Syllis prolifera Krohn, 1852 
Typosyllis microoculata Hartmann-Schröder, 1965, 18(1): 66-76. Licher (1999): 133, fig. 60 .

Syllis prolifera San Martín (2003): 344, figs. 186, 187.

Specimens of Typosyllis microoculata described by Hartmann-Schröder (1965) from Hawaii (Paratypes, HZM P-14498) were examined and their characteristic papillae were found to be in fact misinterpreted ciliate protozoans (Fig. 7A). Without these "papillae" Typosyllis microoculata is identical to the Mediterranean Syllis prolifera, and thus considered a synonymy.

As suggested by previous authors (San Martín, 2003; Gil, 2011) a similar situation might be occurring with Parapionosyllis papillosa, which was described bearing papillae on intersegmental furrows, with a remarkable similarity to ciliate epibionts described herein (Fig. 7B). However, we were not able to study the type material and therefore, we cannot be sure about the taxonomical status of this species.

\section{Discussion}

This is the first study formally reporting the presence of peritrich ciliate protozoans living as epibionts of several polychaete species of the family Syllidae. Despite previous studies already suggested that the diagnostic character "papillae” used to describe some species, could be parasitic ciliates (San Martín, 2003; Gil, 2011) this epibiotic association was not previously confirmed. The occurrence of peritrich ciliates as epibionts of invertebrates is ubiquitous in marine ecosystems but, surprisingly, there are just a handful of studies describing epibiotic associations between the aforementioned protozoans and polychaete annelids. Knox \& Hicks (1973) found numerous specimens of Vorticella spp. on the dorsal surface of the anterior end of the body of the onuphid Brevibrachium maculatum (Estcourt, 1966) (as Rhamphobranchium maculatum) from New Zealand. Magagnini \& Verni (1988) discovered epibiotic peritrich ciliates of the genus Scyphidia living in association with the archiannelid Nerilla antennata Schdmit, 1848 from Italy, and more recently Arias et al. (2010) reported the presence of Epystilis sp. on the gills and first parapodia of the onuphid Diopatra marocensis Paxton, Fadlaoui \& Lechapt, 1995 from northern Spain. Several Rhabdostyla species have also been described as epibionts of polychaetes from 
different families (see Table 3). Only Magagnini \& Verni (1988) pointed out the possible biological and ecological implications for both partners, discarding parasitism as no external damage was observed in the host, even when ciliates were present in large numbers. Accordingly, they defined the association as a classical example of ectocommensalism (sensu Puytorac et al., 1987).

Ciliate associations have been traditionally reported in crustaceans, where detrimental effects on host linked to the presence of epizoic protozoa seemed to be the rule. For instance, they may compete for food or cause negative effects on locomotion or sensory functions turning hosts either more vulnerable to predation or less competitive with non-infected crustaceans (Herman \& Mihursky, 1964; Herman et al., 1971; Evans et al., 1981; Nagasawa, 1986; Scott \& Thune, 1986; Kankaala \& Eloanta, 1987; Nagasawa, 1988). In some cases, even the basibionts life is threatened due to the asphyxiation caused by occlusion of functional respiratory surface by the physical presence of large numbers of protozoans on the gills (Lightner, 1975; Fisher, 1977; Couch, 1978). However, the presence of peritrich ciliates can also benefit their host, since some of them contain toxins that may act as defenses against predation (Henebry \& Ridgeway, 1979). In turn, all authors agree that increased food availability is the major advantage obtained by the epibionts from being associated to a motile substratum. It is not the focus of this study to evaluate the potential benefits or disadvantages that this epibiosis might provide to syllids, however, no impairment of swimming efficiency, or other external harm, was noticed in the specimens carrying ciliate protozoans studied herein. To this end, future studies would be certainly required.

The fact that the epibiotic association between syllids and ciliates has been so rarely observed and reported in a group that has been extensively studied, particularly during the last 30 years, is certainly intriguing. Many authors have largely discussed on the ecological importance of protozoans in aquatic ecosystems and their possible use as bioindicators, because they usually thrive in oxygen poor waters (e.g., Spoon, 1965; Antipa, 1977; Fisher, 1977; Scott \& Thune, 1986). Global warming and other climatological events might lead to lowered oxygen content of the world oceans (Keeling \& García, 2002), and therefore the anthropogenically induced hypoxia in the seawater may have strong consequences on marine symbiotic associations. Interestingly, all our newly collected samples were obtained from harbors or gathered in the vicinity of anthropogenically-disturbed zones, and therefore the induced hypoxia 
may be suggested as one of the causes explaining the presence of ciliated peritrich protozoans in our syllid specimens, although no measurements of oxygen content have been obtained yet. However, P. papillosa was described by Pierantoni (1903) in Northern Italy and T. microoculata by Hartmann-Schroder (1965) in Hawaii, and at those times they were also carrying similar ciliate protozoans. We ignore if those specimens were collected from reportedly organically enriched areas, and therefore, alternative explanations for the presence of symbiotic protozoans might either be a rising number of epibionts per host (for still unknown biological or ecological reasons) or, more likely, a recent increased dedication of the observers. Additionally, the effects of global warming on the protozoans ecology might generate a shift on hosts that could explain their more frequent detection on syllids (Vickerman, 1992).

Regardless of the causes of this newly reported epibiosis, there is a remarkable taxonomic implication affecting the species descriptions within the family Syllidae. Given the cases of P. papillosa and T. microoculata, we might expect an overestimation of the number of syllid species. There might be other cases where the presence of “papillae” (i.e. misinterpreted protozoans) may have been a key character leading to distinguish one "species" from another, especially when preserved specimens are observed (which is a common practice in taxonomic studies). The fixation method used to preserve polychaetes leads to the contraction of the ciliate epibionts, which coupled with their small size poses serious difficulties to differentiate them from simple papillae. Furthermore, this argument may certainly be extensive to other polychaete families (e.g. Sphaerodoriidae), and therefore we strongly suggest assessing the real origin of papillae-like structures in polychaetes in routine identification protocols.

\section{Acknowledgements}

We would like to specially thank Sylvain Faugeron and Federico Rengifo (Pontificia Universidad Católica de Chile), as well as Ricardo Calderón, Randy Finke, Alba Medrano, Elliot Ramos, Hector Sebastian López, Carlos Henriquez, Marta Blanco, Cristina Ruano, Miguel Andreu, Tamara Medina, Marcia Gonzalez, Catalina Riquelme, Jose Miguel Castro, Álvaro Oñate, Jorge Mallén, Luis Viguer, and Miguel Solans who kindly provided support and help to PA-C and AV during their visit to ECIM (Chile). We are also thankful to Sergi Taboada and Juan Moles (UB), Rocío Pérez-Portela (CEAB), Eduardo López (UAM) and Isabel Carmona (Universidad Mayor de San 
Marcos) for their help sampling and sorting material. Many thanks also to Esperanza Salvador, Enrique Rodríguez and Isidoro Poveda (SIDI, UAM), and María Jose Carbonell (CEAB) for help with SEM observations. We are also grateful to Harry Ten Hove for sending references on serpulid-associated protozoans and Joao Gil for his comments on P. papillata. PA-C was supported by a FPI fellowship of the Spanish Ministry of Innovation and Science, AV was funded by a Science Scholarship from the Graduate Center of the City University of New York, and AR acknowledges support by a Juan de la Cierva contract of the Spanish Ministry of Economy and Knowledge. This research has received funding from the European Community's (European Atomic Energy Community's) Seventh Framework Program ([FP7/2007-2013] [FP7/20072011]) under grant agreement $n^{\circ} 227799$ to PA-C and AV. Additional support came from grant CGL2009-12292 BOS of the Spanish Ministry of Economy and Knowledge to GSM, and internal funds of the Consolidated Research Group of the Generalitat de Catalunya on Marine Benthic Ecology (2009SGR655) to DM.

\section{References}

Álvarez-Campos P, San Martín G. \& Aguado MT. 2013. A new species and new record of the commensal genus Alcyonosyllis Glasby \& Watson, 2001 and a new species of Parahaplosyllis Hartmann-Schröder, 1990, (Annelida: Syllidae: Syllinae) from Philippines Islands. Zootaxa 3734 (2): 156-168.

Álvarez-Campos P, San Martín G, Aguado, MT. 2012. The genus Branchiosyllis Ehlers, 1887 from Philippines Islands, with the description of two new species. Zootaxa 3542:49-68.

Antipa GA. 1977. Use of commensal protozoa as biological indicators of water quality and pollution. Transactions of the American Microscopical Society 96 (4): 482489.

Arias A, Anadón N, Paxton H. 2010. New records of Diopatra marocensis (Annelida: Onuphidae) from northern Spain. Zootaxa 2691: 67-68.

Baldock BM. 1986. Peritrich ciliates epizoic on larvae of Brachycentrus subnubilus (Trichoptera): importance in relation to the total protozoan population in streams. Hydrobiologia 132: 125-131. 
Barel CDN, Kramers PGN. 1977. A survey of the echinoderm associates of the NorthEast Atlantic area. Zoologische Verhandelingen, Leiden, 159 pp.

Boucher DH, James S, Keeler KH. 1982. The ecology of mutualism. Annual Review of Ecology and Systematics 13: 315-347.

Britayev TA, Zamyshliak EA. 1996. Association of the commensal scaleworm Gastrolepidia clavigera (Polychaeta: Polynoidae) with holothurians near the coast of South Vietnam. Ophelia 45: 175-190.

Britayev TA, Fauchald K. 2005. New species of symbiotic scaleworms Asterophilia (Polychaeta, Polynoidae) from Vietnam. Invertebrate Zoology 2: 15-22.

Britayev TA, Martin D. 2005. Scale-worms (Polychaeta, Polynoidae) associated with chaetopterid worms (Polychaeta, Chaetopteridae), with description of a new genus and species. Journal of Natural History 39: 4081-4099.

Bush AO, Fernández JC, Esch GW, Seed JR. 2001. Parasitism: The diversity and ecology of animal parasites. Cambridge University Press. 575 pp.

Campoy A. 1982. Fauna de España. Fauna de Anélidos Poliquetos de la Península Ibérica. EUNSA (Ediciones de la Universidad de Navarra), Publicaciones de Biología de la Universidad de Navarra, Serie Zoológica, 7(1), Pamplona. 781 pp.

Corliss JO. 1961 The Ciliated Protozoa: Characterization, Classification, and Guide to the Literature. Pergamon Press, London and New York. 310 pp.

Corliss, J. O. (1979) The Ciliated Protozoa: Characterization, Classification, and Guide to the Literature, 2nd ed. Pergamon Press, Oxford and New York. 455 pp.

Couch, J.A. (1978) Disease, parasites and toxic responses of commercial penaeid shrimps of the Gulf of Mexico and South Atlantic Coasts of North America. Fisheries Bulletin, 76: 1-44.

Cuénot L. 1891. Infusoires commensaux des Ligies, Patelles et arenicoles. Revue Biologique du Nord de la France 4: 81-89.

Dales RP. 1957. Interrelations of organisms. A. Commensalism. In: Treatise on marine ecology and palaeecology (Ed. J.W. Hedgpeth). Memorials of the Geological Society of America, 67: 391-412. 
Dons C. 1918. Neue marine Ciliaten und Suctorien. TromsØ Museums Aarschefter, 3839 (year 1915-1916): 75-100.

Entz G. 1884. Uber infusorien des Golfes von Neapel. Mitteilung der zoologischen station in Neapel 5: 289-444.

Fauvel P. 1923. Faune de France 5. Polychètes Errantes. Le Chevalier Eds. Paris 486 pp.

Fernández-Leborans G, Castro de Zaldumbide M. 1986. The morphology of Anophrys arenicola sp. nov. (Ciliophora, Scuticociliatida). Journal of Natural History 20(3): 713-721.

Fernandez-Leborans G, Tato-Porto ML. 2000. A review of the species of protozoan epibionts on crustaceans. I. Peritrich ciliates. Crustaceana 73: 643-684.

Fernández-Leborans G, Sorbe JC. 2003. A New Protozoan of the Genus Cothurnia (Ciliophora, Peritrichia), Epibiont on the Marine Tanaid Halmyrapseudes spaansi (Crustacea Peracarida) from the French Guiana (SE America). Zoologischer Anzeiger - A Journal of Comparative Zoology 242 (3): 267-275.

Fernández-Leborans G, Gabilondo R. 2006. Inter-annual variability of the epibiotic community on Pagurus bernhardus from Scotland. Estuarine Coastal and Shelf Science 66: 35-54.

Fernández-Leborans G. 2010. Epibiosis in Crustacea: an overview. Crustaceana 83(5): 549-640.

Fisher WS. 1977. Epibiotic microbial infestations of cultured crustaceans Proceedings of the Annual Meeting of the World Mariculture Society 8: 673-684.

Gil J. 2011. The European fauna of Annelida Polychaeta. Unpublished D. Phil. Thesis, Universidade de Lisboa.

Gilbert JJ, Schröder T. 2003. The ciliate epibiont Epistylis pygmaeum: selection for zooplankton hosts, reproduction and effect on two rotifers. Freshwater Biology 48: 878-893.

Glasby CJ, Watson C. 2001. A new genus and species of Syllidae (Annelida: Polychaeta) commensal with octocorals. The Beagle, Records of the Northern Territory Museum of Arts and Sciences17: 43-51. 
Glasby CJ, Schroeder PC, Aguado MT. 2012. Branching out: a remarkable new branching syllid (Annelida) living in a Petrosia sponge (Porifera: Demospongiae). Zoological Journal of the Linnean Society 164: 481-497.

Hartmann-Schröder G. 1965. Zur Kenntnis der eulitoralen Polychaetenfauna von Hawaii, Palmira und Samoa. Abhandlungen und Verhandlungen des Naturwissensschaftlichen Vereins in Hamburg 9: 81-161.

Hartmann-Schröder G. 1983. Zur Kenntnis einiger Foraminiferengehäuse bewohnender Polychaeten aus dem Nordostatlantik. Mitteilungen aus dem Hamburgischen zoologischen Museum und Institut 80: 169-176.

Henebry MS, Ridgeway BT. 1979. Epizoic ciliated protozoa of planktonic copepods and cladocerans and their possible use as indicators of organic water pollution. Transactions of the American Microscopical Society 98 (4): 495-508.

Henry SM. 1966) Symbiosis. I. Associations of Microorganisms, Plants and Marine Organisms. New York \& London: Academic Press.

Hernández CE, Muñoz G, Rozbaczylo N. 2001. Poliquetos asociados con Austromegabalanus psittacus (Molina, 1782) (Crustacea: Cirripedia) en Península Gualpén, Chile Central: Biodiversidad y efecto del tamaño del sustrato biológico. Revista de Biología Marina y Oceanografía, 36 (1): 99 - 108.

Herman SS, Mihursky JA. 1964. Infestation of the copepod Acartia tonsa with the stalked ciliate Zoothamnium. Science 146: 543-544.

Herman SS, Coull BC, Brickman LM. 1971. Infestation of harpacticoid copepods (Crustacea) with Ciliate Protozoans. Journal of Invertebrate Pathology 17: 141142.

Kahl A. 1930-1935. Urtiere oder Protozoa. I: Wimpertiere oder Ciliata (Infusoria), eine Bear-beitung der freilebenden und ectocommensalen Infusorien der Erde, unter Ausschluss der marinen Tintinnidae. In Dahl, F., ed., Die Tierwelt Deutschlands, G. Fischer, Jena, parts 18 (year 1930), 21 (1931), 25 (1932), 30 (1935), pp. 1886.

Kahl A. 1933. Ciliata libera et ectocommensalia. In Grimp, G. and Wagler, E. (eds.) Die Tierwelt der Nord und Ostsee 1: 29-183. 
Kankaala P, Eloranta P. 1987. Epizoicciliates (Vorticellasp.) compete for food with their host Daphnia longispina in a small polyhumic lake. Oecologia 73: 203206.

Keeling RF, García HE. 2002. The change in oceanic $\mathrm{O}_{2}$ inventory associated with recent global warming. Proceedings of the National Academy of Sciences 99: 7848-7853.

Kent WS. 1880-81. A manual of the infusoria, including a description of all known flagellate, ciliate, and tentaculiferous protozoa, British and foreign and an account of the organization and affinities of the sponges. David Bogue, London.

Knox GA, Hicks K. 1973. The polychaetes of New Zealand Part 5. Onuphidae, Journal of the Royal Society of New Zealand 3(2): 281-294.

Lattig P, Martin D. 2009. A taxonomic revision of the genus Haplosyllis Langerhans, 1887 (Polychaeta: Syllidae: Syllinae). Zootaxa 2220: 1- 40.

Lattig P, Martin D, Aguado MT. 2010. Four new species of Haplosyllis (Polychaeta: Syllidae: Syllinae) from Indonesia. Journal of the Marine Biological Association of the United Kingdom 90(4): 789-798.

Lattig P, Martin D. 2011a. Sponge-associated Haplosyllis (Polychaeta: Syllidae: Syllinae) from the Caribbean Sea, with the description of four new species. Scientia Marina 75(4): 733-758.

Lattig P, Martin D. 2011b. Two new endosymbiotic species of Haplosyllis (Polychaeta: Syllidae) from the Indian Ocean and Red Sea, with new data on $H$. djiboutiensis from the Persian Gulf. Italian Journal of Zoology 78(S1): 112-123.

Lightner DV. 1975. Some potentially serious disease problems in the culture of penaeid shrimp in North America. In: Proceedings of the Third US-Japan Meeting on Aquaculture, Tokyo, Japan, pp. 75-97.

Lynn DH, Small EB. 2000. Phylum Ciliophora. In Lee, J. J., Leedale, G. F. and Bradbury, P. (Eds): The Illustrated Guide to the Protozoa, Allen Press, Lawrence: 371-656.

Magagnini G, Verni F. 1988. Epibiosis of Scyphidia sp. (Ciliophora, Peritrichida) on Nerilla antennata (Archiannelida, Nerillidae). Bolletin of Zoology 3: 185-189. 
Martin D, Britayev TA. 1998. Symbiotic polychaetes: Review of known species. Oceanography and Marine Biology: an Annual Review 36: 217-340.

Martin D, Núñez J, Riera R, Gil J. 2002. On the associations between Haplosyllis (Polychaeta, Syllidae) and gorgonians (Cnidaria, Octocorallaria), with the description of a new species. Biological Journal of the Linnean Society 77: 455477.

Möbius K. 1888. Bruchstücke einer Infusorienfauna der Kieler Bucht. Archiv für Naturgeschichte 81-116.

Morgado EH, Amaral, ACZ. 1985. Anelídeos poliquetos associados ao briozoário Schizoporella unicornis (Johnston). V. Syllidae. Revista Brasileira de Biologia 3: 219-227.

Nagasawa S. 1986. The peritrich ciliate Zoothamnium attached to the copepod Centropages abdominalis in Tokio Bay waters. Bulletin of Marine Science 38: 553-558.

Nagasawa S. 1988. The copepod Centropages abdominalis as a carrier of the stalked ciliate Zoothamnium. Hydrobiologia 167/168: 255-258.

Noland LE, Finley HE. 1931. Studies on the taxonomy of the genus Vorticella. Transactions of American Microscopical Society 50 (2): 81-123.

Precht H. 1935. Epizoen der Kieler Bucht. Nova Acta Leopold 3: 405-475.

Pierantoni U. 1903. La gestazione esterna (Contributo alla biologia de alla embriologia dei Sillidi). Archivio Zoologico 1: 231-252.

Puytorac de P, Grain J, Mignot JP. 1987. Précis de Protistologie. Societé Nouveau Edit. Boubée, Paris, 581 pp.

Rangel LF, Santos MJ, Cech G, Székely C. 2009. Morphology, molecular data, and development of Zschokkella mugilis (Myxosporea, Bivalvulida) in a polychaete alternate host, Nereis diversicolor. The Journal of Parasitology 95(3): 561-569.

Regali-Seleghim MH, Godinho MJL. 2004. Peritrich epibiont protozoans in the zooplankton of a subtropical shallow aquatic ecosystem (Monjolinho Reservoir, São Carlos, Brazil). Journal of Plankton Research 26 (5): 501-508.

Reynoldson TB. 1942. Vorticella as an indicator organism for activated sludge. Nature 
149: 608-609.

Rhode K. 1981. The nature of parasitism. In: Heatwole H, ed. Australian Ecology Series: Ecology of marine parasites. St. Lucia: University of Queensland Press, $1-5$.

San Martín G. 1992. Syllis Savigny in Lamarck, 1818 (Polychaeta: Syllidae: Syllinae) from Cuba, the Gulf of Mexico, Florida and North Carolina, with a revision of several species described by Verrill. Bulletin of Marine Science 51(2): 167-196.

San Martín G. 2003. Familia Syllidae. In: Annelida, Polychaeta II. Fauna Ibérica, vol. 21 (ed. M.A. Ramos). Museo Nacional de Ciencias Naturales, CSIC, Madrid. $554 \mathrm{pp}$.

San Martín G. 2005. Exogoninae (Polychaeta: Syllidae) from Australia with the description of a new genus and twenty-two new species. Records of the Australian Museum 57: 39-152.

Sedlacek L, Thistle D, Fernandez-Leborans G, Carman KR, Barry JP. 2013. First report of ciliate (Protozoa) epibionts on deep-sea harpacticoid copepods. Deep-Sea Research II 92: 165-171.

Simon C, San Martín G, Robinson G. (In press) Two new species of Syllis (Polychaeta: Syllidae) from South Africa, one of them viviparous, with remarks on larval development and vivipary. Journal of the Biological Marine Association of the United Kingdom.

Small EB. 1973. A study of ciliate Protozoa from a small polluted stream in east-central Illinois. American Zoology 13: 225-230.

Smith ME. 1986. Distribution Patterns and Seasonal Occurrence of Rhabdostyla sp. (Peritricha: Epistylididae) on Dero nivea (Oligochaeta: Naididae). American Midland Naturalist 116, (2): 348-355.

Scott JR, Thune RL. 1986. Ectocommensal protozoan infestations of gills of red swamp crawfish, Procambarus clarkii (Girard), from commercial ponds. Aqua- culture 55: $161-164$.

Spoon DM. 1965. Field and laboratory studies of the ecology of sessile ciliates with possible application to rapid assessment of water pollution. M. S. Thesis, Emory University, At-lanta, Georgia. 135 pp. 
Stiller J. 1939. Die peritrichen fauna der Nordsee bei Helgoland. Archiv fur Protistenkunde 92: 415-452.

Stiller J. 1968 Peritriche Ciliaten ökologisch verschiedener Biotope von Rovinj und Umgebung. Acta Zoologica Academiae Scientiarum Hungaricae 14: 185-211.

Taboada S, Junoy J, Andrade S, Giribet G, Cristobo J., Ávila C. (2013) On the identity of two Antarctic brooding nemerteans: redescription of Antarctonemertes valida (Bürger, 1893) and description of a new species in the genus Antarctonemertes Friedrich, 1955 (Nemertea, Hoplonemertea). Polar Biology 36:1415-1430.

Vickerman K. 1992. The diversity and ecological significance of Protozoa. Biodiversity and Conservation 1: 334-341.

Wahl M. 1989 Marine epibiosis. I. Fouling and antifouling: some basic aspects. Marine Ecology Progress Series 58: 175-189.

Wakeman KC \& Leander BS. 2013. Molecular phylogeny of marine gregarine parasites (Apicomplexa) from tube-forming Polychaetes (Sabellariidae, Cirratulidae, and Serpulidae), including descriptions of two new species of Selenidium. The journal of Eukaryotic Microbiology 60 (5): 514-525.

Warren A, Paynter J. 1991. A revision of Cothurnia (Ciliophora: Peritrichida) and its morphological relatives. Bulletin of the British Museum (natural History), (Zoology) 57: 17-59.

Weissman P, Lonsdale DJ, Yen J. 1993. The effect of peritrich ciliates on the production of Acartia hudsonica in Long Island Sound. Limnology and Oceanogaphy 38(3): 613-622.

Westheide W. 1974. Interstitielle Fauna von Galapagos. XI. Pisionidae, Pilargidae, Syllidae. Mikrofauna des Meeresbodens 44: 195-338.

\section{Figure legends}

Figure 1. Cothurnia kiwi n. sp. on Prosphaerosyllis magnoculata (MNCN 39.02/8). A) Scanning electron micrograph of the anterior part of $P$. magnoculata showing several individuals of $C$. kiwi n. sp. (arrows). B-C) Close-up micrographs of the 
epibiont C. kiwi n. sp. on the intersegmental furrows of the annelid. D) Light microscopy picture of the stained protozoan showing the lorica (l) and the external stalk (es).

Figure 2. Line drawings of the new species of ciliate protozoans. A) Cothurnia kiwi n. sp. (MNCN 39.01/5). B) Rhabdostyla mapuche n. sp. (MNCN MNCN 39.02/12). C) Rhabdostyla taboadai n. sp. (MNCN 39.02/25) Abbreviations: l, lorica; ma, macronucleus; mi, micronucleus; ms, mesostyle; es, external stalk; pd, persitomial disk; s, stalk; bd, basal disk.

Figure 3. Light microscopy pictures of Rhabdostyla mapuche n. sp. on different Syllidae species. A) Anterior part of Salvatoria sp. (MNCN 39.02/21) showing several individuals of $R$. mapuche n. sp. (arrows). B) Close-up picture of the epibiont on the intersegmental furrows of the syllid. C) Stained protozoan on Syllis sp. 1 (MNCN 39.02/16) showing the macronucleus (ma) and micronucleus (mi). D) Anterior part of Salvatoria concinna n. comb. (MNCN 39.02/24) showing several individuals of the epibiont (arrows). E) Close-up picture of the epibiont on the intersegmental furrows of the syllid. F) Close-up picture of epibiont showing the stalk (s) and vacuoles (v). G) Anterior part of Syllis sp. 2 (MNCN 39.02/20) showing several individuals of the epibiont (arrows). H) Close-up micrograph of the epibiont on the intersegmental furrows of the syllid. I) Close-up micrograph of epibiont showing the lorica (l), vacuoles, the micronucleus, macronucleus and the stalk.

Figure 4. Rhabdostyla n. spp. on different Syllidae species. A) Scanning electron micrographs of the anterior end in ventral view of Syllis sp. 2 (MNCN 39.02/20) showing one epibiont in the base of tentacular cirri. B) Anterior and midbody segments, dorsal view, of Syllis sp. 2 showing several ciliates (arrows). C) Close-up micrograph of the epibiont on the intersegmental furrows of Syllis sp. 2. D) Close-up micrograph, lateral view, of two ciliates showing the stalk (arrows). E) Close-up micrograph of an epibiont, apical view. F) Transmission electron micrograph of $R$. mapuche n. sp. on Syllis sp. 1 (MNCN 39.02/16). Note the arrow pointing to the basal part of the epibiont. G) Scanning electron micrograph of Rhabdostyla taboadai n. sp. on Syllis prolifera (MNCN 39.02/26), showing the stalk (arrow). 
Figure 5. Light microscopy pictures of Rhabdostyla taboadai n. sp. on Syllis prolifera (MNCN 39.02/25) A) Anterior part of the syllid showing an individual of $R$. taboadai n. sp. (arrow). B-D) Close-up pictures of the epibiont on the intersegmental furrows of the syllid showing the stalk (arrow) and the peristomial disk (pd).

Figure 6. Scanning electron micrographs of unidentified Rhabdostyla species on two Syllidae species. A) Anterior end of Syllis elongata (MNCN 39.02/15296) showing several individuals of Rhabdostyla sp. 1 (arrows). B-C) Close-up micrographs of the epibiont on intesegmental furrows and tentacular cirri of $S$. elongata, showing the stalk (arrow). D) Posterior ventral part of Typosyllis macropectinans (AM W.41626) showing several individuals of Rhabdostyla sp. 2 (arrows). E-F) Close-up micrographs of the ciliates showing the stalk (arrow).

Figure 7. A) Light microscopy picture of Syllis prolifera (originally described as Typosyllis microoculata) from Hawaii (HZM.P.14498) showing the epibiotic ciliates on the intersegmental furrows (arrows). B) Line drawing (modified from Pierantoni, 1903) of Parapionosyllis papillosa from Italy, showing the epibiotic ciliates on the intersegmental furrows (arrows).

Table 1. Epibiotic ciliate protozoans identified in Syllidae polychaetes.

Table 2. Comparison between Cothurnia kiwi n. sp. and the most similar species of the genus.

Table 3. Comparison between Rhabdostyla new species and the most similar species of the genus. 
A

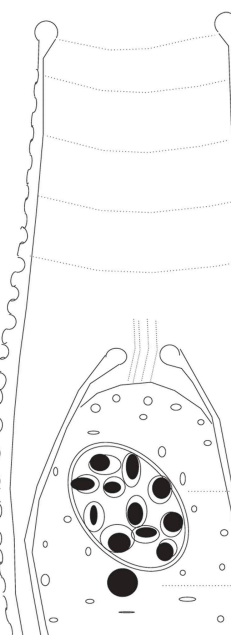

I

ma

mi

ms

es

B

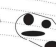

?:

pd

ma

mi

S

pd

ma 


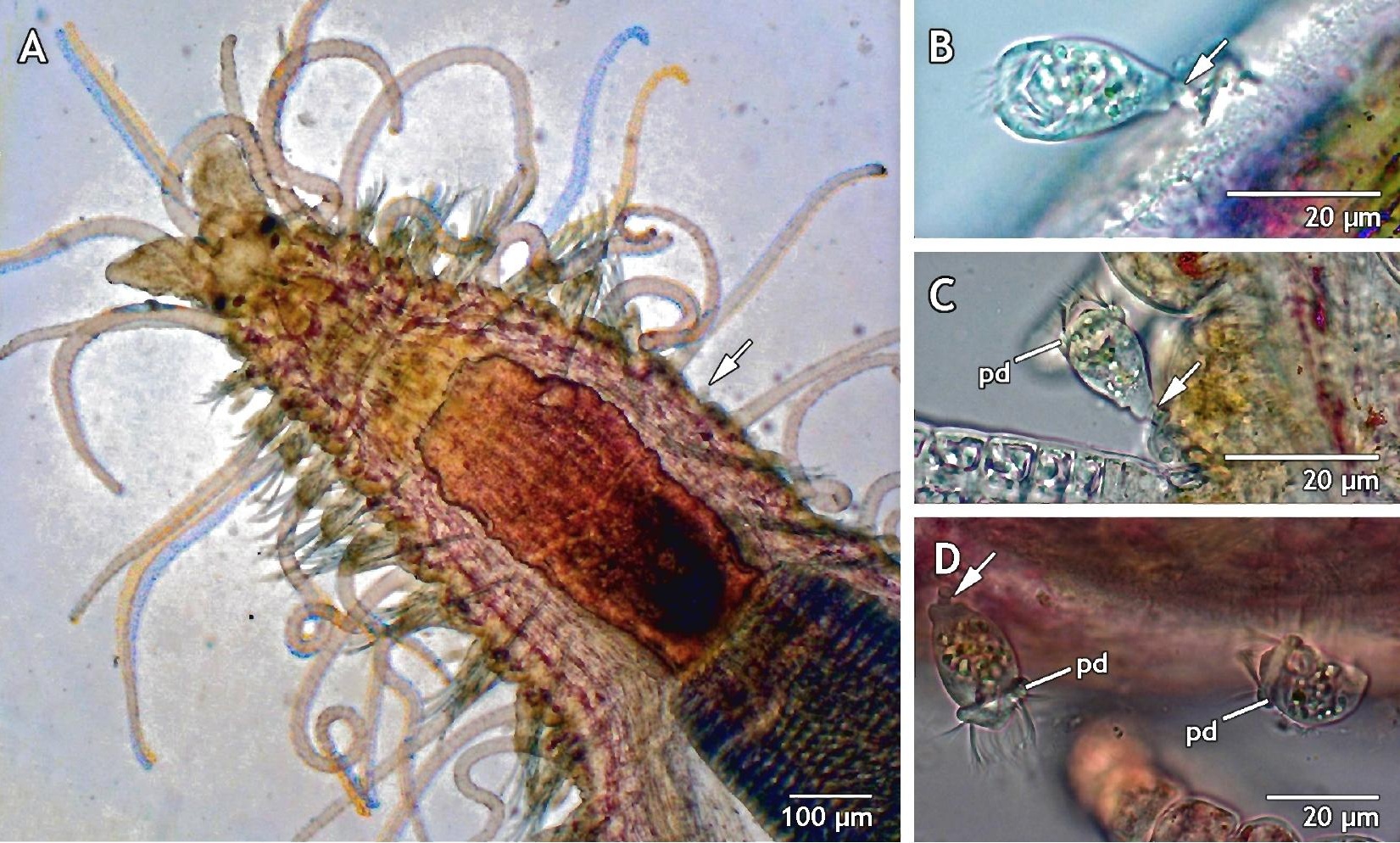




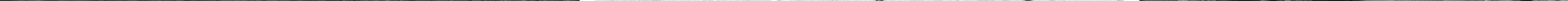




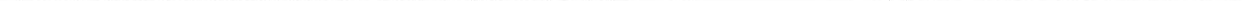




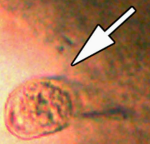

D)
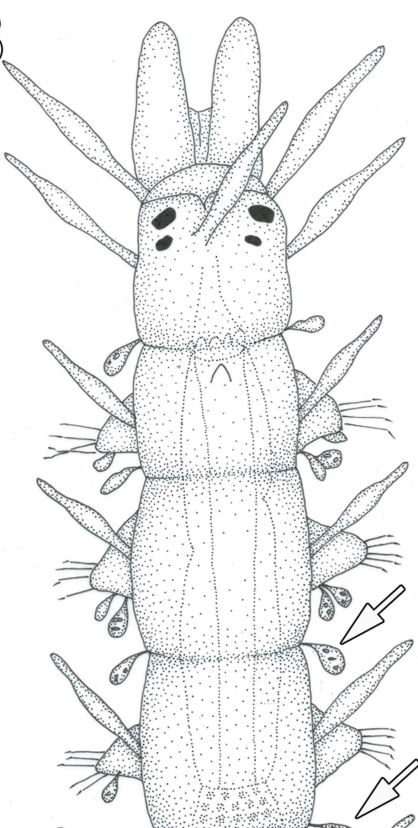

4

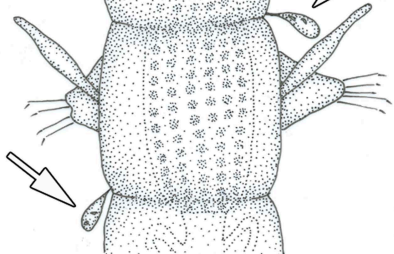




\section{Newly collected specimens}

\begin{tabular}{|c|c|c|c|c|c|}
\hline \multirow{3}{*}{$\begin{array}{l}\text { Cothurnia kiwi } \\
\quad \text { n. sp. }\end{array}$} & \multirow{3}{*}{$\begin{array}{l}\text { Prosphaerosyllis } \\
\text { magnooculata }\end{array}$} & Wellers Rock, Dunedin, New Zealand & $45^{\circ} 50.52^{\prime} \mathrm{S}, 170^{\circ} 37.31^{\prime} \mathrm{E}$ & Feb $7^{\text {th }}, 2012$ & $\begin{array}{c}\text { Holotype MNCN 39.01/5 } \\
2 \text { Paratypes MNCN 39.02/6-7 } \\
\text { 1 Paratype SEM MNCN 39.02/8 }\end{array}$ \\
\hline & & $\begin{array}{c}\text { Tauranga Bay, Cape Foulwind, New } \\
\text { Zealand }\end{array}$ & $41^{\circ} 46.23^{\prime} \mathrm{S}, 171^{\circ} 27.12^{\prime} \mathrm{E}$ & Feb $9^{\text {th }}, 2012$ & 2 Paratypes MNCN 39.02/9-10 \\
\hline & & Akaroa Bay, New Zealand & $43^{\circ} 48.50^{\prime} \mathrm{S}, 172^{\circ} 57.15^{\prime} \mathrm{E}$ & Feb $5^{\text {th }}, 2012$ & 1 Paratype MNCN 39.02/11 \\
\hline \multirow{6}{*}{$\begin{array}{l}\text { Rhabdostyla } \\
\text { mapuche n. sp. }\end{array}$} & Typosyllis magdalena & Las Cruces, Valparaíso Region, Chile & $33^{\circ} 30.06^{\prime} \mathrm{S}, 71^{\circ} 37.55^{\prime} \mathrm{W}$ & Jan $14^{\text {th }}, 2013$ & $\begin{array}{c}\text { Holotype MNCN 39.02/12 } \\
3 \text { Paratypes MNCN 39.02/13-15 }\end{array}$ \\
\hline & Syllis sp.1 & Las Cruces, Valparaíso Region, Chile & $33^{\circ} 30.06^{\prime} \mathrm{S}, 71^{\circ} 37.55^{\prime} \mathrm{W}$ & Jan $14^{\text {th }}, 2013$ & 1 Paratype MNCN 39.02/16 \\
\hline & \multirow{2}{*}{ Syllis sp.2 } & Las Cruces, Valparaíso Region, Chile & $33^{\circ} 30.06^{\prime} \mathrm{S}, 71^{\circ} 37.55^{\prime} \mathrm{W}$ & Jan $14^{\text {th }}, 2013$ & 3 Paratypes MNCN 39.02/17-19 \\
\hline & & Las Cruces, Valparaíso Region, Chile & $33^{\circ} 30.06^{\prime} \mathrm{S}, 71^{\circ} 37.55^{\prime} \mathrm{W}$ & Jan $14^{\text {th }}, 2013$ & 1 Paratype MNCN 39.02/20 \\
\hline & Salvatoria sp. & Las Cruces, Valparaíso Region, Chile & $33^{\circ} 30.06^{\prime} \mathrm{S}, 71^{\circ} 37.55^{\prime} \mathrm{W}$ & Jan $14^{\text {th }}, 2013$ & 1 Paratype MNCN 39.02/21 \\
\hline & Salvatoria concinna & Las Cruces, Valparaíso Region, Chile & $33^{\circ} 30.06^{\prime} \mathrm{S}, 71^{\circ} 37.55^{\prime} \mathrm{W}$ & Jan $14^{\text {th }}, 2013$ & 3 Paratypes MNCN 39.02/22-24 \\
\hline $\begin{array}{l}\text { Rhabdostyla } \\
\text { taboadai n. sp. }\end{array}$ & Syllis prolifera & Punta Santa Anna, Blanes, Spain & $41^{\circ} 40.25^{\prime} \mathrm{N}, 02^{\circ} 48.06^{\prime} \mathrm{E}$ & Sep $23^{\text {rd }}, 2013$ & $\begin{array}{c}\text { Holotype MNCN 39.02/25 } \\
\text { 1 Paratype MNCN 39.02/26 } \\
1 \text { Paratype SEM 39.02/27 }\end{array}$ \\
\hline Rhabdostyla sp.1 & Syllis elongata & Albacora, Tumbes, Peru & $12^{\circ} 08.37^{\prime} \mathrm{S}, 77^{\circ} 01.36^{\prime} \mathrm{W}$ & Mar, 2013 & $\begin{array}{c}3 \text { specimens SEM MNCN } \\
16.01 / 15296\end{array}$ \\
\hline \multicolumn{6}{|c|}{ Revised museum specimens } \\
\hline Rhabdostyla sp. & $\begin{array}{l}\text { Typosyllis } \\
\text { macropectinans }\end{array}$ & $\begin{array}{c}\text { North of Batemans, New South Wales, } \\
\text { Australia }\end{array}$ & $36^{\circ} 43.59^{\prime} \mathrm{S}, 149^{\circ} 59.16^{\prime} \mathrm{E}$ & Mar $16^{\text {th }}, 2004$ & AM.W41626 \\
\hline Rhabdostyla sp. & Typosyllis microoculata & Maui, Hawaii & $\begin{array}{c}20^{\circ} 45.09^{\prime} \mathrm{N} \\
156^{\circ} 29.26^{\prime} \mathrm{W}\end{array}$ & May $19^{\text {th }}, 1959$ & 1 Paratype HZM.P-14498 \\
\hline
\end{tabular}

\footnotetext{
*Catalogue numbers for newly collected specimens correspond to ciliate epibionts. Catalogue numbers for revised museum specimens represent Syllidae species.
} 


\begin{tabular}{|c|c|c|c|c|c|c|}
\hline Lorica length $(\mu \mathrm{m})$ & 60 & 50 & 60 & 70 & $40-45$ & $40.9-53.1$ \\
\hline Lorica width $(\mu \mathrm{m})$ & 30 & 30 & 25 & 35 & $18-23$ & $16.8-19.2$ \\
\hline Lorica striation & central annular & smooth & furrows and ridges & smooth & smooth & $\begin{array}{c}\text { furrows and ridges } \\
\text { center thicker }\end{array}$ \\
\hline Lorica aperture & 15 & 20 & $?$ & 30 & 20 & $10.5-13.7$ \\
\hline Body length $(\mu \mathrm{m})$ & 60 & 70 & 80 & 45 & $55-57$ & $26-36$ \\
\hline Body width $(\mu \mathrm{m})$ & $8-10$ & 15 & 20 & 20 & $12-15$ & $14.7-16.6$ \\
\hline Mesostyle & - & - & + & + & - & + \\
\hline Endostyle & - & - & + & + & + & - \\
\hline $\begin{array}{c}\text { External stalk } \\
\text { length }(\mu \mathrm{m})\end{array}$ & $\begin{array}{l}\text { short, bulbous in } \\
\text { attachment lorica }\end{array}$ & short & 15 & 35 & $8-12$ & $11.1-22.5$ \\
\hline $\begin{array}{l}\text { Macronucleus } \\
\text { shape }\end{array}$ & $\begin{array}{c}\text { straight, } \\
\text { longitudinal }\end{array}$ & c-shaped, transversal & $?$ & curved, longitudinal & $?$ & oval, anterior \\
\hline Basibiont & Harpacticoida & $?$ & Harpacticoida & Cytheridea sp. & Cladophora sp. & $\begin{array}{c}\text { Prosphaerosyllis } \\
\text { magnoculata }\end{array}$ \\
\hline Distribution & Tyrrhenian Sea & North Sea & $?$ & $?$ & Adriatic Sea & New Zealand \\
\hline References & Entz, 1884 & Stiller, 1939 & Kahl, 1933 & Kahl, 1933 & Stiller, 1968 & \\
\hline
\end{tabular}




\begin{tabular}{|c|c|c|c|c|c|c|c|c|}
\hline & $\begin{array}{l}\text { Rhabdostyla } \\
\text { libera }\end{array}$ & $\begin{array}{l}\text { Rhabdostyla } \\
\text { commensalis }\end{array}$ & $\begin{array}{l}\text { Rhabdostyla } \\
\text { arenaria }\end{array}$ & $\begin{array}{c}\text { Rhabdostyla } \\
\text { nereicola }\end{array}$ & $\begin{array}{l}\text { Rhabdostyla } \\
\text { scyphoides }\end{array}$ & $\begin{array}{l}\text { Rhabdostyla } \\
\text { variabilis }\end{array}$ & $\begin{array}{c}\text { Rhabdostyla } \\
\text { mapuche } \mathrm{n} . \mathrm{sp} .\end{array}$ & $\begin{array}{c}\text { Rhabdostyla } \\
\text { taboadai } \mathrm{n} . \mathrm{sp} .\end{array}$ \\
\hline Body shape & slight & barrel-shaped & $?$ & $?$ & cylindrical & $?$ & oval spheroid & oval elongated \\
\hline Length $(\mu \mathrm{m})$ & $?$ & $?$ & 56 & $55-62$ & $?$ & $60-90$ & $23-31$ & $30-45$ \\
\hline Width $(\mu \mathrm{m})$ & $?$ & $?$ & $?$ & $?$ & $?$ & $?$ & $16-19$ & $15-23$ \\
\hline $\begin{array}{c}\text { Oral disk shape and } \\
\text { length }(\mu \mathrm{m})\end{array}$ & $?$ & $\begin{array}{l}\text { papillary } \\
\text { projection }\end{array}$ & $?$ & sheet-like & $\begin{array}{l}\text { broad, not } \\
\text { elevated }\end{array}$ & $?$ & $\begin{array}{l}\text { broad, convex } \\
\text { elevated }(20-23)\end{array}$ & $\begin{array}{c}\text { broad, convex } \\
\text { elevated }(26-29)\end{array}$ \\
\hline Ma shape & $?$ & $\begin{array}{l}\text { sausage-shaped, } \\
\text { short central }\end{array}$ & $\begin{array}{l}\text { ribbon-shaped, } \\
\text { very long }\end{array}$ & $?$ & $?$ & kidney-shaped & $\begin{array}{l}\text { c-shaped, } \\
\text { longitudinal }\end{array}$ & multilobed \\
\hline Body striation & $\begin{array}{l}\text { thin, } \\
\text { longitudinal }\end{array}$ & $?$ & $?$ & $?$ & pellicle, smooth & $?$ & transversal & transversal \\
\hline Stalk striation & & $?$ & $?$ & $?$ & $?$ & $?$ & longitudinal & longitudinal \\
\hline Stalk length $(\mu \mathrm{m})$ & short & $?$ & 10 & $?$ & $?$ & $?$ & $3-6$ & $14-17$ \\
\hline Stalk width $(\mu \mathrm{m})$ & $?$ & $?$ & $?$ & $?$ & $?$ & $?$ & $4-6$ & $7-9$ \\
\hline $\begin{array}{c}\text { Basal disk length } \\
(\mu \mathrm{m})\end{array}$ & $?$ & $?$ & $?$ & $?$ & $?$ & $?$ & - & $8-12$ \\
\hline Basibiont & $\begin{array}{l}\text { Algae and } \\
\text { aquaria walls }\end{array}$ & $\begin{array}{l}\text { Capitella } \\
\text { capitata, } \\
\text { Terebellides } \\
\text { ströemii }\end{array}$ & $\begin{array}{c}\text { Synapta } \\
\text { inhaerens, } \\
\text { Asterias } \\
\text { rubens, } \\
\text { Leptosynapta } \\
\text { sp., } \\
\text { Astropecten sp. }\end{array}$ & Nereis dimerii & $\begin{array}{l}\text { Penaeus } \\
\text { orientalis }\end{array}$ & $\begin{array}{l}\text { Scoloplos } \\
\text { armiger, } \\
\text { Phyllodoce } \\
\text { laminosa }\end{array}$ & $\begin{array}{c}\text { Syllis magdalena, } \\
\text { Syllis sp.1, Syllis } \\
\text { sp.2., Salvatoria } \\
\text { concinna, } \\
\text { Salvatoria sp. }\end{array}$ & Syllis prolifera \\
\hline Distribution & $?$ & $?$ & $\begin{array}{l}\text { Baltic Sea, } \\
\text { Germany }\end{array}$ & $\begin{array}{l}\text { Baltic Sea, } \\
\text { Germany }\end{array}$ & $?$ & $\begin{array}{l}\text { Baltic Sea, } \\
\text { Germany }\end{array}$ & $\begin{array}{c}\text { Pacific Ocean, } \\
\text { Central Chile }\end{array}$ & $\begin{array}{c}\text { North-Eastern } \\
\text { Mediterranean Sea, } \\
\text { Spain }\end{array}$ \\
\hline References & Kahl, 1933 & Möbius, 1888 & Cuenot, 1891 & Precht, 1935 & Song, 1986 & Dons, 1918 & & \\
\hline
\end{tabular}

